home, promising that he would come to me/which is particularly remarkable in those in a month.

He wrote to me several times during the summer ; it was impossible for him to come up; but the remaining portion gave him no pain to speak of. He returned to me at the end of last October. On sounding, $T$ ascertained that the calculus was in the membranous part of the urethra, which was dilated: this was not only sensible to the touch by the instrument, but obvious, both from the sound's passing readily by it into the bladder, and the largeness of the stream of urine. Preferring to comminute it in the bladder, rather than in the uretbra, I took an exploring bougie, and forming the wax at its extremity into a knob as large as the orifice of the urethra would admit, I carried it down to the calculus, after pressing gently against it for about half a minute, the bougie advanced softly, carrying the stone before it into the bladder. I then withdrew the exploring bougie ; it presented, exactly in its centre, an indentation of the fragment; a sound. now passed down, no longer met it in the membranous part of the urethra.

He came to me the next morning to tell me, that it was again come into the urethra, and he thought lower down; he felt heat in the rectum, and pain in making water. I felt the stone in its old place in the urethra; I passed a small lithotrite down to it; as soon as I came in contact with it, I slid the point of the lithotrite past it, so as to place the branches of the instrument and the stone in parallelism with each other; I then turned the lithotrite, so that two branches were made to open gradually upon two opposite sides of the stone; as soon as the expansion was sufficient, the stone dropped into the grasp of the instrument. As it could not be brought away whole, it was perforated, and pressed in two. The instrument being now withdrawn, the fragments were carried out by the next flow of urine. Not a drop of blood uas shed in this operation. 'This. was the nucleus of the stone, and was evidently the renal calculus which descended into the bladder in 1811; it was excessively hard, quite black, and apparently vitrified; its surface was smooth and polished, but there was still adherent to it, as if to elucidate the bistory of the entire calculus, a small prominent patch of the lithic acid incrustation with which it bad become enveloped to so considerable an extent while in the bladdier; this patch corresponded exactly with the impression impartel to the exploring bougie which I had used in putting it back in to the bladder.

This case shows that the long continuance of the disease does not exclude the patient from the benefit of lithotrity, a fact

who are attacked by it, in the earlier or middle periods of life. It is true that the sufferings which the presence of the stone produces in persins at these times of life, may be equally or even more acute than in those who have passed the " grand climacteric"; still the alterations of tissues so fre. quent in old persons, are often absent in younger people, even where the disease has existed a longer time, and in a more severe form. I have had ample experience of the truth of this 'observation. This case also shows, that a stone, the size of a pullet's egg, was successfully assailed by the lithotrite. If. however, I had had in my posses. sion, at the time this case presented itself, a safo percussor, I should have used it, as I bave since done frequently on larger and harder stones.

The gentlemen who witnessed this ope. ration were, Sir C. Bell, Dr. Yelloly of Norwich, Drs. Sigmond, Gilkrest, Blicke, Uwins, Mr. Hetling of Bristol, Messrs. Kingdon, Harding, Evans, Thomas Boorman, Prater, Vardy, Samwell, Davey, Hunt, Costello, \&c.

Sir II. Halford had kindly signified his intention of being present, but unfortu. nat $\in$ ly was unable to attend.

7, Parliament-street, Westminster, March 1, 1833.

\section{PREPARATION OF CHLORINE IN SCARLET FEVER.}

\section{To the Editor of The LANCET.}

SI R,-Having just read Dr. Alexander's second paper in your valuable hebdomadary for Feb. 23rd, with much interest, I beg to mention, with all due deference to Dr. Alex. ander, that in the typhoid form of scarlatina, where the Doctor points out the necessity of "bark, wine, and various tonies," I have lately, in addition to the above remedies, pre:cribed, with astonishing benefit, the following preparation of chlorine :-

\section{Re Potassa orymur. $3 \mathrm{ij}$;} Acidi muriatici;

Aq. dist. aa $3 \mathrm{zj} ;$ solve, ut ft. mistura, cujus capiat Pharmacopula quantitalem infira dictum, ad mist:eram sumendum.

Bo Mistura ut supra, $.5 \mathrm{ij}$; Aq. distillate

vel

Alius aq. dist. $5 v j$ j. Ft. mist. cujus capiat partem 4tam, 4ta quaq. horâ.

*Ita in MS.-ED. L. 
If the term "specific" may be allowed in the nomenclature of "licensed practitioners," this medicine may claim it. 1 have also administered this medicine per anum, and $b r$ its powerful disinfecting properties, have found it cleanse the bowels from the putrescent diarrboal discharges so irritat. ing and distressing to the patient.

As I have no wish to arrogate to myself the credit of this discovery, il beg leave to state, that some years ago it was brought to my notice by Mr. Brown, an intelligent practitioner at Lewisham in Kent; therefore, "Palmam qui meruit ferat." $\mathrm{M}_{\mathrm{Y}}$ object in bringing the fact before the medi. cal public is, that my professional brethren may give it a trial, and, if successfully, their meel of praise. I have the horiour to be, Sir, yours very respectfully, Jamis Bright.

Brigliton, Feb. 26th, 1833.
NEW PLAN FOR TREATING

\section{DEFORMITY OF THE FOOT.}

By E. L. BRyan, Esq., Surgeon, Sloumarket.

A воuт ten months since $I$ was called to two cases of club-foot in infants, aged about five or six weeks. The occasion led me to reflect on the subject of congenital deformity of the foot, and after some consideration I commenced a method of treatment which proved successful, and incluced me to try a somewhat similar plan in the following case :-

Ann Wright, residing at Stowmarket, was brought to me in July last, on account of the pain and inconvenience which she suffered from a malformation of the right foot, represented in the following plate, fig. 1.
Fig. 1.

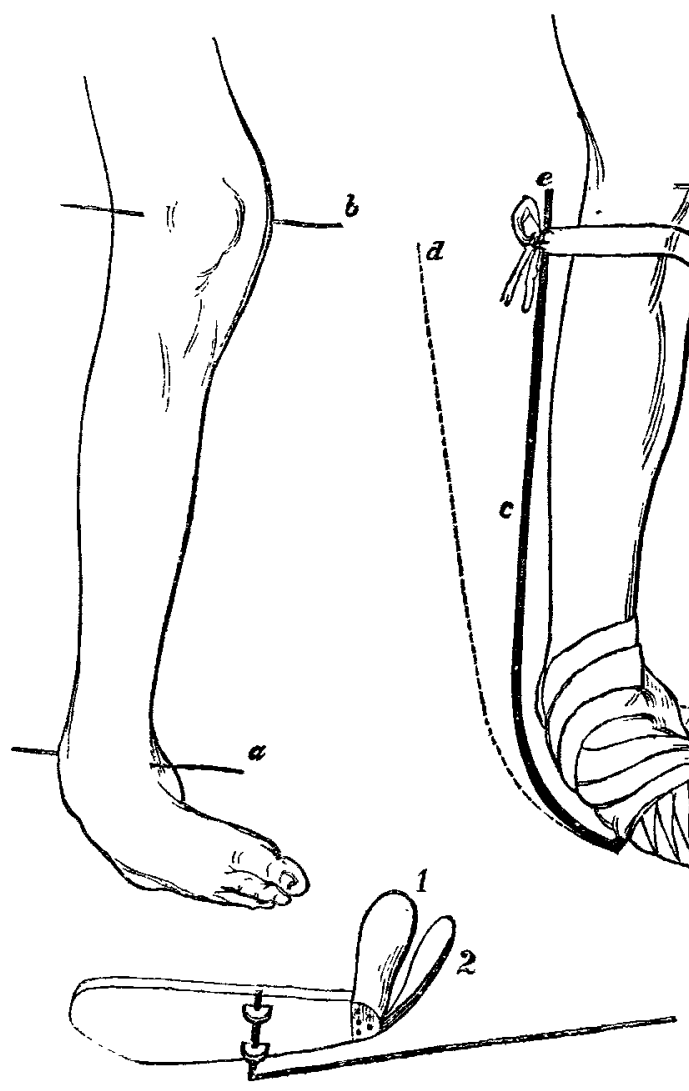

Fig. 4.
Fig. 2.

Fig. 3. 